\title{
The use of mechanical ventilation systems with heat recovery to ensure air quality in residential premises
}

\author{
Uladzimir Navaseltsau, Dzina Navaseltsava, Vitali Khaletski* \\ Department of Engineering Systems and Ecology, Brest State Technical University, 224017, Republic of Belarus
}

\begin{abstract}
The construction industry is an important segment of the national economy of the Republic of Belarus. In recent years, strict environmental safety requirements have been imposed on the quality of housing being built. The carbon dioxide content in the classrooms' air of the university as model objects was investigated by the authors. It has been shown that the content of this pollutant can exceed 2,000 ppm. The use of mechanical ventilation systems, especially with heat recovery, allows to solve the problem of poor air quality in residential premises. However, for the successful functioning of ventilation systems, systematic training of the inhabitants and the implementation of educational programs are required.
\end{abstract}

\section{Introduction}

General state of human body is closely related to air quality. Staying in rooms with poor air quality leads to a deterioration in the functional state of the body, contributes to the spread of a number of diseases, reduces work performance.

In the Republic of Belarus, when designing residential buildings, specialists are guided by the interstate standard GOST 30494-2011 "Residential and public buildings. Indoor microclimate parameters" [1]. According to this document, carbon dioxide is the main pollutant that determines indoor air quality. Indoor air quality depends on the carbon dioxide content and can correspond to four classes (table 1).

Table 1. Classification of indoor air

\begin{tabular}{ccc}
\hline Type & Air quality & $\begin{array}{c}\text { Permissible content of } \mathrm{CO}_{2}, \\
\text { ppm, in addition to carbon } \\
\text { dioxide in the air }\end{array}$ \\
\hline 1 & High & 400 and less \\
\hline 2 & Medium & $400-600$ \\
\hline 3 & Acceptable & $600-1000$ \\
\hline 4 & Low & 1000 and more \\
\hline
\end{tabular}

In recent years, a number of studies have appeared devoted to the determination of carbon dioxide in the air of educational institutions and residential premises, as well as the assessment of the potential toxicity of low levels of $\mathrm{CO}_{2}$ [2-8]. Data collected by various authors have shown significant concentrations of carbon dioxide in the internal air in various countries. Typically, the $\mathrm{CO}_{2}$ content exceeds $1,000 \mathrm{ppm}$, in some cases reaching a maximum value of $6,000 \mathrm{ppm}$.

Meanwhile, back in the 1960s, O.V. Eliseeva conducted detailed studies to substantiate the norms of $\mathrm{CO}_{2}$ in the air of residential and public buildings. It was investigated how carbon dioxide affects the human body in concentrations of $1,000 \mathrm{rpm}$ and $5,000 \mathrm{rpm}$. It was concluded that short-term inhalation of carbon dioxide by healthy people at these concentrations causes distinct changes in the function of external respiration, blood circulation, and electrical activity of the brain [9].

Modern studies also associate the effects of low doses of $\mathrm{CO}_{2}$ with respiratory diseases, including rhinitis, asthma, dry cough, dry mucous membranes, and neurophysiological symptoms (headache, fatigue, difficulty concentrating). Traditionally, this complex of diseases is associated with Sick Building Syndrome (SBS). Most authors consider the concentration of $\mathrm{CO}_{2}$ to be at a safe level of 1,000 rpm [10-11].

Indoor $\mathrm{CO}_{2}$ levels are currently the primary indicator of air quality. It acts as an indicator gas, by which it is possible to judge not only about other pollutants, but also about how effectively the ventilation system in the building works. If, in addition to carbon dioxide, volatile organic compounds and formaldehyde are present in the air, it is sufficient to monitor only $\mathrm{CO}_{2}$.

The aim of this work was to experimentally determine the carbon dioxide content in the classrooms of Brest State Technical University as a model object, as well as to analyze the effectiveness of mechanical ventilation systems with heat recovery as a method of improving indoor air quality.

\section{Study of air quality in the classrooms of the Brest State Technical University}

Determination of carbon dioxide concentration was carried out using the multifunctional Testo 435 instrument, operating on the basis of IR spectroscopy. $\mathrm{CO}_{2}$ detection limits are $0-10,000 \mathrm{ppm}$, resolution $1 \mathrm{ppm}$.

vgnovoseltsev@yandex.ru

*Corresponding Author: email: vitali.khaletski@gmail.com; phone/ fax: +375 162321704 
The study was conducted in the heating season. Ambient temperature outside the building was $-2^{\circ} \mathrm{C}$, the temperature inside the auditorium was $+18-20^{\circ} \mathrm{C}$, the carbon dioxide content in the air was $400 \mathrm{ppm}$.

To study the state of air, 7 classrooms of building №2 of Brest State Technical University were selected. Carbon dioxide concentrations were measured before and after classes in classrooms. Studies showed that even before classes began, classrooms had a fairly high $\mathrm{CO}_{2}$ content, more than 2 times the atmospheric background. During the training session (1.5 hours), the concentration of $\mathrm{CO}_{2}$ reaches critical values, exceeding in some cases 2,500 ppm. Data on carbon dioxide concentrations are given in table 2 .

Table 2. The concentration of $\mathrm{CO}_{2}$ in the air of the audience.

\begin{tabular}{ccc}
\hline \multirow{2}{*}{ Classroom } & \multicolumn{2}{c}{$\mathrm{CO}_{2}$ concentration in air, ppm } \\
\cline { 2 - 3 } & before a class & after a class \\
\hline 1 & 831 & 2706 \\
\hline 2 & 780 & 1227 \\
\hline 3 & 815 & 1461 \\
\hline 4 & 859 & 2536 \\
\hline 5 & 855 & 2228 \\
\hline 6 & 1091 & 1233 \\
\hline 7 & 819 & 2224 \\
\hline
\end{tabular}

Obviously, the air quality in the classrooms does not meet the required values. This is due to the fact that the windows in the rooms do not provide for air infiltration, because of this, the existing natural ventilation system does not provide the necessary air exchange. This problem is present in most similar buildings for various purposes, residential and public.

\section{Study of the operation of mechanical ventilation systems with heat recovery of energy-efficient buildings in the Brest region of the Republic of Belarus}

One of the most effective solutions to the problem of poor air quality in the premises of residential and public buildings is the use of mechanical ventilation systems, especially with heat recovery.

As model samples, we studied four energy-efficient residential buildings with a mechanical system of supply and exhaust ventilation with heat recovery. The buildings are located in the Brest region of the Republic of Belarus:

-building 1, Drahičyn city, built in 2014,

-building 2, Malaryta city, built in 2012,

-building 3, Pinsk city, built in 2011,

-building 4, Pinsk city, built in 2011.

The results of a study of the mechanical ventilation systems of these buildings by the authors of the article are given below.

\subsection{Description of the device and the functioning of the mechanical ventilation system of energy-efficient houses with recovery access (buildings $1,2,3$ )}

Ventilation is designed centralized supply and exhaust with mechanical motivation and heat recovery. The scheme of the ventilation system involves the installation of a supply and exhaust unit for each section of a residential building (there are 2 sections in the house). Units are installed in the attic in ventilation chambers. Fresh supply air is heated in the heat exchanger-heat exchanger with the heat of the exhaust air. To heat the air to the required temperature is the built-in electric heater. From the installation through the duct system, air enters the living quarters and kitchens of the apartments. For the flow of air from living rooms to the hallway, corridors, kitchen, bathroom and bathroom, flow grilles are installed in the doors of these rooms. Air removal is provided from kitchens $-90 \mathrm{~m}^{3} / \mathrm{h}$, from bathtubs -25 $\mathrm{m}^{3} / \mathrm{h}$. To remove air from the bathrooms $\left(25 \mathrm{~m}^{3} / \mathrm{h}\right)$ duct fans are installed. To clean the kitchen air, an electric air purifier is installed, as well as a grille with a filter on the air duct. In the event that mechanical ventilation will not work, the electrically operated valve will open a natural exhaust duct. The bathroom also has a channel for natural extraction with a grill installed on it with manual adjustment of the live section. In the apartment, air ducts are laid under a suspended ceiling. Air distribution is carried out by ceiling diffusers.

As a result of the study of the mechanical ventilation system of energy-efficient houses, the following was established:

1.The mechanical ventilation system does not operate on an ongoing basis in buildings 2 and 3. Inspection of the ventilation chamber showed that the equipment installed in is in accordance with the project and is in working condition.

2.As a result of the study of the ventilation system of the apartments, it was found that in some apartments (up to $6 \%$ ), electric valves on the ventilation grids were dismantled and the ventilation holes were completely sealed as a result of the repair.

3.According to the results of the survey and measurements of air velocities, it was found that in many channels of natural ventilation there is a reverse draft (overturning of ventilation). This problem is also indicated by $36 \%$ of residents (survey data).

\subsection{Description of the device and functioning of the mechanical ventilation system of energy-efficient houses with apartment-by-apartment recovery (building 4)}

Ventilation is designed for supply and exhaust with heat recovery. The scheme of the ventilation system involves the placement of the ventilation unit AVTU-150 in the apartment, in the utility room. Fresh supply air through a duct system laid under a suspended ceiling, through diffusers, is fed into the living rooms and kitchen of the apartment. Air removal is provided from the kitchen - 90 
$\mathrm{m}^{3} / \mathrm{h}$, bathrooms and toilets $-25 \mathrm{~m}^{3} / \mathrm{h}$. Air from the living quarters enters the hallway, corridors and toilets through transfer grilles installed in the doors of the premises. When mechanical ventilation is turned on, the natural exhaust duct in the kitchen is closed by an automatic shut-off valve with an electric actuator. The air in the kitchens is cleaned by an electric air purifier and through a removable ceiling grill with a filter RS-1 (400x 100). The toilet room has a Vents $125 \mathrm{~K}$ duct fan, which is activated when the light is turned on.

As a result of the study of the mechanical ventilation system of an energy-efficient house, the following was established:

1.According to research and questionnaires, only 4 apartments are constantly operating the mechanical ventilation system. In 4 apartments, heat recovery units are generally dismantled. According to the survey of residents of the house, the reasons for not using the mechanical ventilation system were determined:

-increased power consumption $(40,5 \%)$,

-increased noise $(13,5 \%)$,

-intake of cold air from the system (10,8\%),

-dismantling the system $(10,8 \%)$,

-other reasons $(24,4 \%)$.

2. The air temperature in the room is $22-23^{\circ} \mathrm{C}$ (at the time of the study, $22.7^{\circ} \mathrm{C}$ with an air humidity of $38.8 \%$ ), and the mechanical ventilation system is used only at night. during the day, if necessary, ventilation is carried out by opening the windows.

It should be noted that the average electricity consumption in this apartment is the largest of all apartments in the house ( $243 \mathrm{kWh}$ with an average electricity consumption of $156 \mathrm{kWh}$ per apartment).

We can conclude that with the regular use of the mechanical ventilation system, the consumption of electricity consumed by the apartment increases quite significantly, which leads to limited use by the residents of the system.

Thus, the mechanical ventilation system of energyefficient houses is mainly in working condition, but does not function due to the lack of interest of residents in its work, mainly due to the high consumption of electricity consumed by heat recovery units.

\section{Conclusions}

In the vast majority of modern buildings with natural ventilation, normative air exchange is not ensured, which leads to poor indoor air quality.

One of the most effective solutions to the problem of poor air quality in the premises of residential and public buildings is the use of mechanical ventilation systems, especially with heat recovery. However, at present, in the Republic of Belarus, the lack of significant savings when paying for heat and electric energy does not inspire confidence in energy-efficient houses with mechanical ventilation systems.

Thus, the urgent measure in the transition to energyefficient construction is constant, systematic propaganda of the importance of ensuring the necessary air exchange for the person in the media (popular TV shows, conversations with specialists, advertising on billboards, newspaper publications). This will create a favorable attitude among the population towards energy-efficient houses and the notion that even with a slightly higher cost of utilities in the apartments of such houses, the apartments will provide much better conditions for the functioning of the human body in the air environment and microclimate in general.

\section{References}

1. ГОСТ 30494-2011 Здания жилые и общественные. Параметры микроклимата в помещениях. - дата введения 01.01.2013. - 11c. (in Russian)

2. Muscatiello, N., McCarthy, A., Kielb, C., Hsu, W.H., Hwang, S.A., Lin, S. (2015) Classroom conditions and $\mathrm{CO} 2$ concentrations and teacher health symptom reporting in 10 New York State Schools. Indoor Air, 25(2): 157-167.

3. Gaihre, S., Semple, S., Miller, J., Fielding, S., Turner, S. (2014) Classroom carbon dioxide concentration, school attendance, and educational attainment. Journal of School Health, 84(9): 569-574.

4. Branco, P.T.B.S., Alvim-Ferraz, M.C.M., Martins, F.G., Sousa, S.I.V. (2015) Children's exposure to indoor air in urban nurseries-part I: $\mathrm{CO} 2$ and comfort assessment. Environmental Research, 140: $1-9$.

5. Jurado, S.R., Bankoff, A.D.P., Sanchez, A. (2014) Indoor air quality in Brazilian universities. International journal of environmental research and public health, 11(7): 7081-7093.

6. Ferreira, A.M., Cardoso, M. (2014) Indoor air quality and health in schools. Jornal Brasileiro de Pneumologia, 40(3): 259-268.

7. Bierwirth, P.N. (2018) Carbon dioxide toxicity and climate change: a major unapprehended risk for human health. Web Published: ResearchGate DOI:10.13140/RG.2.2.16787.48168

8. Гурина, И.В. (2010) Кто ответит за духоту в помещении. Химия и жизнь: XXI век, 2: 28-31. (in Russian)

9. Елисеева, О.В. (1964) К обоснованию ПДК двуокиси углерода в воздухе. Гигиена и санитария, 8: 16-21. (in Russian)

10. Sung Ho Hwang, Jaehoon Roh, Wha Me Park (2018) Evaluation of PM10, $\mathrm{CO} 2$, airborne bacteria, TVOCs, and formaldehyde in facilities for susceptible populations in South Korea. Environment Pollution, 242(a): 700-708.

11. Губернский, Ю.Д., Гошин, М.Е., Калинина, Н.В., Банин, И.М. (2016) Обоснование допустимого уровня содержания диоксида углерода в воздухе помещений жилых и общественных зданий. Гигиена и санитария, 95 (4): 329-335. (in Russian) 